Jurnal Agro 8(2), 2021

\title{
PENGARUH PEMUPUKAN N TERHADAP SERAPAN DAN EFISIENSI PENGGUNAAN N, SERTA HASIL PADI HIBRIDA
}

\section{THE EFFECTS OF NITROGEN FERTILIZER ON NITROGEN UPTAKE, NITROGEN USE EFFICIENCY AND YIELD OF HYBRID RICE VARIETIES}

\author{
Risqa Naila Khusna Syarifa, Zulfa Ulinuha, Purwanto* \\ Jurusan Agroteknologi, Fakultas Pertanian Universitas Jenderal Soedirman \\ JI. Dr. Suparno KP 125, Purwokerto 53122 \\ *Korespondensi : purwanto.unsoed@gmail.com
}

Diterima : 25 November 2021 / Disetujui : 30 Desember 2021

\begin{abstract}
ABSTRAK
Pemupukan $\mathrm{N}$ pada padi hibrida menjadi krusial mengingat varietas padi hibrida sangat responsif, sehingga harus diketahui dosis yang tepat untuk menghasilkan produksi yang tinggi. Penelitian ini bertujuan untuk mengkaji pengaruh dosis $\mathrm{N}$ terhadap serapan $\mathrm{N}$, efisiensi penggunaan $\mathrm{N}$, dan hasil padi hibrida. Penelitian menggunakan Rancangan Acak Kelompok yang diulang tiga kali. Faktor pertama adalah varietas padi hibrida yang terdiri dari Varietas Mapan P05, Varietas SL-8SHS Sterling, dan Varietas Intani 602. Faktor kedua adalah dosis pemupukan $\mathrm{N}$ yang terdiri dari kontrol tanpa pemupukan $\mathrm{N}$, dosis $\mathrm{N} 100 \mathrm{~kg} \mathrm{ha}^{-1}$, dan dosis $\mathrm{N} 200 \mathrm{~kg} \mathrm{ha}^{-1}$. Terdapat respon yang beragam antar varietas padi hibrida terhadap taraf pemupukan $\mathrm{N}$, Serapan $\mathrm{N}$, efisiensi penggunaan $\mathrm{N}$ tertinggi yang dihasilkan oleh varietas Intani 602 masingmasing sebesar $138,57 \%$, dan $36,13 \%$. Serapan $\mathrm{N}$ tanaman padi tertinggi dicapai pada dosis $\mathrm{N}$ $100 \mathrm{~kg} \mathrm{ha}^{-1}$, dan efisiensi penggunaan $\mathrm{N}$ tertinggi pada dosis $\mathrm{N} 200 \mathrm{~kg} \mathrm{ha}^{-1}$. Hasil gabah tertinggi dicapai pada varietas Mapan P05 sebesar 7,42 t ha-1, dan dosis pemupukan N $100 \mathrm{~kg} \mathrm{ha}^{-1}$ memberikan hasil tertinggi sebesar 7,47 $\mathrm{t} \mathrm{ha}^{-1}$. Implikasi dari penelitian ini bahwa dosis nitrogen $100 \mathrm{~kg} \mathrm{ha}^{-1}$ dapat menjadi acuan sebagai dosis pemupukan $\mathrm{N}$ varietas padi hibrida di Indonesia.

Kata kunci: Efisiensi, Hibrida, Nitrogen, Padi, Serapan
\end{abstract}

\section{ABSTRACT}

Hybrid rice is responsive to nitrogen, so it's necessary to find the optimum dose to optimize the production. The aims of this research was to examine the effect of nitrogen on $\mathrm{N}$ uptake, $\mathrm{N}$ use efficiency, and yield of hybrid rice. This study used a randomized block design with three replications. The first factor consisted of Mapan P05 variety, the SL-8SHS Sterling variety, and Intani 602 variety. The second factor was Nitrogen dosage consisted of control, $100 \mathrm{~kg} \mathrm{ha}^{-1}$, and $200 \mathrm{~kg} \mathrm{ha}^{-1}$. There were various responses among hybrid rice varieties to the level of fertilization. The highest $\mathrm{N}$ uptake and $\mathrm{N}$ use efficiency was achieved in the Intani 602 variety at $138.57 \%$ and $36.13 \%$, respectively. The highest $\mathrm{N}$ uptake was achieved at $100 \mathrm{~kg} \mathrm{ha}^{-1}$ of $\mathrm{N}$, and the highest $\mathrm{N}$ use efficiency was at $200 \mathrm{~kg} \mathrm{ha}^{-1}$. The highest yield was achieved in the Mapan P05 variety $\mathbf{7 . 4 2}$ $\left.\mathrm{t} \mathrm{ha} \mathrm{C}^{-1}\right)$, and the dose of $\mathrm{N}$ at $100 \mathrm{~kg} \mathrm{ha}^{-1}$ gave the highest yield $\left(7.47 \mathrm{t} \mathrm{ha}^{-1}\right)$. The implication of this research is that the nitrogen dose of $100 \mathrm{~kg} \mathrm{ha}^{-1} \mathrm{can}$ be used as a reference for hybrid rice varieties fertilizer in Indonesia.

Cite this as: Syarifa, R, N, K., Ulinuha, Z., \& Purwanto. (2021). Pengaruh pemupukan N terhadap serapan dan efisiensi penggunaan $\mathrm{N}$, serta hasil padi hibrida. Jurnal Agro, 8(2), 262-273. https://doi.org/10.15575/15084 
Key words : Efficiency, Hybrid, Nitrogen, Rice, Uptake

\section{PENDAHULUAN}

Padi sebagai komoditas utama penghasil beras mempunyai posisi yang sangat strategis dalam tatanan ekonomi Indonesia. Masyarakat Indonesia sangat tergantung terhadap beras sebagai makanan pokok, sedangkan produksi padi masih terpusat di pulau Jawa. Pulau Jawa memberikan kontribusi sebesar 52 persen dari produksi beras nasional (Septiadi \& Joka, 2019). Disisi lain, luas panen padi nasional terus mengalami penurunan. Luas panen padi tahun 2020 mengalami penurunan seluas 20.61 ribu ha jika dibandingkan luas panen tahun 2019 yang mencapai 10,68 juta ha (BPS, 2021).

Kondisi ini harus diimbangi dengan peningkatan produktivitas. Produktivitas varietas unggul nasional sampai saat ini masih pada kisaran $5 \mathrm{t} \mathrm{ha}^{-1}$. Varietas padi yang cukup besar luasan tanamnya yakni Ciherang produktivitas hanya $5,5 \mathrm{t} \mathrm{ha}^{-1}$, sedangkan varietas inbrida baru seperti Inpari 15, Inpari 20, dan Inpari 22 produktivitas tertinggi baru mencapai 7,5 $\mathrm{t}$ ha ${ }^{-1}$ (Amirrullah et al., 2018).

Terobosan dengan menggunakan varietas hibrida menjadi alternative meningkatkan produktivitas. Fenomena heterosis berdampak positif terhadap kenaikan produksi sampai 30 persen. Varietas Hibrida mampu berproduksi diatas $9 \mathrm{t}$, bahkan varietas Rokan mampu berproduksi mencapai $11,06 \mathrm{t} \mathrm{ha}^{-1}$ lebih tinggi dibanding varietas Ciherang (Satoto \& Suprihatno, 2008). Lebih lanjut Dong et al. (2020) melaporkan bahwa padi hibrida japonica indica mampu menghasilkan gabah diatas $12 \mathrm{t} \mathrm{ha}^{-1}$ atau mengalami kenaikan produksi sampai 32,2 persen dibandingkan varietas inbrida.
Produktivitas padi hibrida di lapangan sangat dipengaruhi oleh faktor lingkungan dan pengelolaan tanaman. Pengelolaan hara makro terutama nitrogen sangat berperan dalam pertumbuhan dan hasil tanaman padi. Nitrogen merupakan komponen penting dari produksi padi, tetapi pemupukan yang berlebihan berdampak negatif terhadap lingkungan melalui pelepasan gas $\mathrm{N}_{2} \mathrm{O}$ (Ramija, 2013).

Padi hibrida sangat responsif terhadap pemupukan sehingga peningkatan dosis $\mathrm{N}$ akan meningkatkan pertumbuhan dan hasil. Pradipta et al. (2017) melaporkan bahwa pemupukan NPK pada padi hibrida galur T1683 sampai dosis $600 \mathrm{~kg} \mathrm{ha}^{-1}$ masih memberikan kenaikan hasil gabah. Setyorini et al. (2020) melaporkan bahwa pemupukan $\mathrm{N}$ semakin tinggi meningkatkan pertumbuhan dan hasil padi, dimana pada tanah berpasir dosis tertinggi mencapai 207 kg N ha-1 atau setara $450 \mathrm{~kg} \mathrm{ha}^{-1}$ Urea. Pada lahan kering dosis optimum pemupukan $\mathrm{N}$ $150 \mathrm{~kg} \mathrm{ha}^{-1} \mathrm{~N}$ (Djaman et al., 2018).

Adopsi teknologi varietas padi hibrida di masyarakat masih rendah walaupun sudah banyak varietas yang beredar. Input yang tinggi terutama nitrogen dan harga benih menjadi salah satu faktor lambatnya penyebaran varietas hibrida. Varietas Mapan P05 merupakan padi hibrida yang sudah banyak disukai masyarakat karena mempunyai umur tanam yang relatif lebih cepat dibandingkan varietas lain dan mempunyai ketahanan terhadap organisme pengganggu tanaman (Muthohharoh et al., 2018). Adapun Varietas Intani 602 memiliki keunggulan tanaman yang lebih kokoh, malai panjang, produksi tergolong tinggi, rendemen tinggi dan rasa nasi yang lebih enak (BISI, 2020). Varietas SL-8SHS Sterling 
memiliki keunggulan antara lain memiliki batang yang kokoh, potensi hasil, dan hasil yang tergolong tinggi (Imran \& Suriany, 2009).

Dalam upaya mendapatkan produktivitas tanaman yang maksimum dan mengurangi dampak negatif pemupukan nitrogen perlu dikaji terkait optimasi dosis nitrogen yang memberikan hasil dan efisiensi pemupukan yang tinggi. Tujuan penelitian ini adalah untuk pengaruh pemupukan $\mathrm{N}$ terhadap serapan $\mathrm{N}$, efisiensi penggunaan $\mathrm{N}$, dan hasil padi hibrida.

\section{BAHAN DAN METODE}

Penelitian ini dilaksanakan di lahan sawah Kebun Percobaan fakultas Pertanian Universitas Jenderal Soedirman Purwokerto dari bulan Februari sampai dengan bulan Mei 2021. Lahan sawah yang digunakan untuk lokasi penelitian dengan jenis tanah Inceptisol. Tanah memiliki tekstur lempung liat berdebu, dan memiliki nilai $\mathrm{pH}$ sebesar 6,5. Kadar C-organik sebesar 2,01 \%, $\mathrm{N}$ total sebesar 0,17\%, dan $\mathrm{C} / \mathrm{N}$ rasio sebesar 12 . Kadar $\mathrm{P}$ total sebesar $0,15 \%$, dan $\mathrm{K}$ total sebesar 0,08\%. Kadar $P$ tersedia sebesar 145 ppm $\mathrm{P}_{2} \mathrm{O}_{5}, \mathrm{~K}$ tersedia sebesar 479 ppm $\mathrm{K}_{2} \mathrm{O}$, serta KTK sebesar 19,96 $\mathrm{cmol} \mathrm{kg}^{-1}$.

Lahan sawah lokasi penelitian berada di pada ketinggian $110 \mathrm{~m}$ dpl $(-7,4059$; 109,2528) dengan jenis tanah Inceptisol dengan analisis tekstur (lempung liat berdebu), pH (Ekstrak 1:5), bahan organik (Waikley \& Black dan Kjedahl), P total dan K total (Total $\left.\left(\mathrm{HNO}_{3}\right)\right), \mathrm{P}$ tersedia (Olsen), $\mathrm{K}$ tersedia (Morgan), nilai basa tertukar, KTK dan kejenuhan basa ( $\mathrm{NH}_{4}{ }^{-}$Acetat $1 \mathrm{~N}$. $\mathrm{PH}$ 7).

Penelitian ini menggunakan Rancangan Acak Kelompok faktorial dan diulang tiga kali. Faktor pertama yang dicoba adalah varietas padi hibrida yang terdiri dari
Varietas Mapan P05 $\left(\mathrm{V}_{1}\right)$, SHS SL $\left(\mathrm{V}_{2}\right)$, dan Varietas Intani $602\left(\mathrm{~V}_{3}\right)$. Faktor kedua adalah dosis $\mathrm{N}$ yang terdiri dari kontrol $\left(\mathrm{N}_{0}\right)$, dosis $\mathrm{N}$ $100 \mathrm{~kg} \mathrm{ha}^{-1}\left(\mathrm{~N}_{1}\right)$, dan dosis $\mathrm{N} 200 \mathrm{~kg} \mathrm{ha}^{-1}\left(\mathrm{~N}_{2}\right)$. Terdapat 9 kombinasi perlakuan dan diulang tiga kali sehingga total terdapat 27 unit percobaan. Petak percobaan berukuran $4 \mathrm{~m}$ x $4 \mathrm{~m}$ dan jarak tanam $25 \mathrm{~cm} \times 25 \mathrm{~cm}$. Bibit tanaman padi hibrida ditanam pada umur 21 hari setelah semai (HSS).

Variabel yang diamati meliputi variabel pertumbuhan, hasil dan komponen hasil. Variabel pertumbuhan meliputi tinggi tanaman $(\mathrm{cm})$, jumlah anakan (batang), indeks luas daun (ILD), bobot kering tanaman (g), kadar klorofil a dan b $\left(\mathrm{mg} \mathrm{g}^{-1}\right)$, aktivitas enzim nitrat reduktase, kerapatan panjang akar $\left(\mathrm{cm} \mathrm{cm}^{-3}\right)$ dan kerapatan stomata. Variabel hasil dan komponen hasil terdiri dari jumlah anakan produktif (batang), panjang malai $(\mathrm{cm})$, bobot seribu biji, persentase gabah isi (\%), dan hasil gabah per ha (t ha-1).

Indeks Luas Daun dihitung dengan metode Rajput et al. (2017). Indek Luas Daun (ILD) diukur dengan formula sebagai berikut.

ILD : $\frac{\text { total luas duan }}{\text { area tanah yang ditempati tanaman }}$

Kadar klorofil diukur dengan menggunakan metode Holden (1965) dalam Proklamasiningsih et al. (2013) dengan ekstraksi menggunakan pelarut organik aceton. Diambil sampel daun tanaman padi umur 8 minggu setelah tanam, dan ditimbang seberat $0,1 \mathrm{~g}$. Sampel daun di gerus menggunakan mortar dan pastle, dan ditambah $10 \mathrm{ml}$ aceton $80 \%$. Ekstrak daun di saring dengan menggunakan kertas saring Whatman no. 4, dan larutan ditampung dalam tabung reaksi. Larutan ekstrak klorofil diukur absorbansinya menggunakan 
spektrofotmeter pada $\lambda 645 \mathrm{~nm}$, dan 663 $\mathrm{nm}$. Kadar klorofil daun dihitung dengan formula berikut :

Klorofil $a=0,0127(O D$ 663) $-0,00269$ (OD 645)

Klorofil $b=0,0229(O D$ 645) $-0,00468$ (OD 663)

Klorofil total $=0,0202$ (OD 645) $-0,00802$ (OD 663)

Laju asimilasi bersih (LAB) di hitung dengan metode Rajput et al. (2017) :

$$
\text { LAB }: \frac{(W 2-W 1)(\ln (L 2)-\ln (L 1)}{(t 2-t 1)(L 2-L 1)} \mathrm{g} . \mathrm{cm}^{-2} \cdot \mathrm{minggu}^{-1}
$$

Dimana : W2 dan W1 bobot kering tanaman pada waktu destruksi pertama dan kedua, L1 dan L2 adalah luas duan tanaman padi pada waktu destruksi pertama dan kedua, t1 dan t2 adalah waktu destruksi tanaman pertama dan kedua.

Laju pertumbuhan tanaman (LPT) dihitung dengan metode (Sridevi \& Chellamuthu, 2015) :

$$
\text { LPT : } \frac{W 2-W 1}{G(t 2-t 1)} \text { g.cm }{ }^{-2} \cdot \text { minggu }^{-1}
$$

Dimana : W1 dan W2 adalah bobot kering tanaman pada destrukti waktu t1 dan t2. G adalah area tanah yang ditempati tanaman.

Analisis nitrogen dalam jaringan tanaman menggunakan metode Kjedahl (Yoshida et al., 1976). Kadar nitrogen dalam jaringan kemudian digunakan untuk menentukan serapan nitrogen tanaman padi dengan formula sebagai berikut :

Serapan N : $=\% N$ jaringan $\times$ Biomassa

Efisiensi penggunaan $\mathrm{N}$ diukur dengan metode (Good et al., 2004) dimana EA di hitung dengan formula sebagai berikut :
NUE $\left(\mathrm{g} \cdot \mathrm{g}^{-1}\right)=\frac{\text { Shoot Weight }}{N}$

Dimana : NUE : efisiensi penggunaan N, Shoot Weight : bobot kering tajuk, N : Kadar $\mathrm{N}$ dalam jaringan tanaman

Aktivitas Nitrat Reduktase (ANR) diukur dengan metode Hartiko (1987) dalam Purbajanti et al. (2010). Daun tanaman padi diambil dan dibersihkan dengan kertas tisu, dan potong kecil-kecil. Sebanyak $300 \mathrm{mg}$ ptongan daun ditempatkan dalam tabung gelap, ditambahkan $5 \mathrm{ml}$ buffer fosfat $\mathrm{pH}$ 7,5, dan daun direndam selama 24 jam. Setelah 24 jam, buffer dibuang dan diganti dengan $4,9 \mathrm{ml}$ buffer fosfat baru, kemudian ditambahkan 0,1 $\mathrm{ml}$ larutan $5 \mathrm{M} \mathrm{NaNO}_{3}$ sebagai substrat enzim nitrat reduktase dan diinkubasi selama 3 jam. Tabung reaksi diisi dengan $0,2 \mathrm{ml}$ larutan sulfanilamida $1 \%$ dan $0,2 \mathrm{ml}$ larutan naftiletilendiamin 0,02\% dalam $\mathrm{HCl} 3 \mathrm{~N}$. Sebanyak $0,1 \mathrm{ml}$ larutan dimasukkan ke dalam tabung reaksi yang telah diisi zat warna nitrit dan ditunggu 10 sampai 15 menit sampai berubah warna menjadi merah muda. 9,5 $\mathrm{ml}$ air suling ditambahkan ke dalam larutan. Larutan dalam tabung dikocok dan dipindahkan ke dalam kuvet, kemudian diukur absorbansinya pada panjang gelombang 540 $\mathrm{nm}$ menggunakan spektrofotometer. ANR dinyatakan sebagai jumlah mol nitrit yang terbentuk per gram berat segar sampel per jam.

$\mathrm{ANR}=\frac{A s}{A 0} \times \frac{1000}{B} \times \frac{1}{T x} \times \frac{500}{1000} \mu_{\mathrm{mol} \mathrm{NO}}{ }^{-} \mathrm{jam}^{-1}$

Dimana :

As : nilai absorbansi larutan sampel

Ao: nilai absorbansi standar $(0,0106$ atau 0,0142)

$B$ : berat segar daun sample $(=300 \mathrm{mg}$ )

$\mathrm{T}$ : waktu inkubasi 
Data dianalisis menggunakan Uji $\mathrm{F}$, dan apabila berbeda nyata namun tidak terdapat interaksi dilanjutkan dengan uji DMRT 5\% pada masing-masing variabel yang berbeda nyata.

\section{HASIL DAN PEMBAHASAN}

Pemupukan $\mathrm{N}$ menunjukkan pengaruh terhadap tanaman padi hibrida. Varietas Intani 602 menunjukkan serapan $\mathrm{N}$ terbaik, bobot kering tanaman serta tingkat efisiensi penggunaan $\mathrm{N}$ yang lebih tinggi dibandingkan Mapan P-05 dan SL-8SHS Sterling (Tabel 1). Karakteristik masingmasing varietas inilah yang menjadikan adanya perbedaan morfologi (tinggi tanaman, luas daun, jumlah anakan) yang kemudian dapat berpengaruh pada proses fisiologi tanaman dengan tingkatan yang berbeda(Peng et al., 2015; Lyu et al., 2020).

Serapan $\mathrm{N}$ tertinggi dihasilkan pada pemberian $\mathrm{N}$ dengan dosis $100 \mathrm{~kg} \mathrm{ha}^{-1}$, dan produksi bahan kering besar (Tabel 1). Palanivell et al. (2015) menyatakan bahwa kecukupan nutrisi khususnya nitrogen akan mendukung produksi biomassa dan laju pertumbuhan tanaman. Hal yang berbeda ditunjukkan pada hasil analisis ragam efisiensi penggunaan $\mathrm{N}$ pada tanaman padi hibrida, dimana tingkat efisiensi penggunaan $N$ tertinggi (35,23\%) dihasilkan pada pemberian $\mathrm{N}$ dengan dosis $200 \mathrm{~kg} \mathrm{ha-1}$. Efisiensi penggunaan $\mathrm{N}$ menunjukkan tingkat keefektifan penggunaan unsur $\mathrm{N}$ yang diberikan kepada tanaman dan yang mampu dipulihkan kembali (Hasanalideh \& Hojati, 2012). Efisiensi penggunaan $N$ tidak dipengaruhi oleh besar kecilnya berat kering tanaman yang dihasilkan (Good et al., 2004), berbeda halnya dengan tingkat serapan $\mathrm{N}$ pada tanaman yang dipengaruhi oleh berat kering yang dihasilkan (Xie et al., 2019).

Tabel 1. Pengaruh dosis $\mathrm{N}$ terhadap serapan $\mathrm{N}$, bobot kering tanaman dan efisiensi penggunaan $\mathrm{N}$ pada tanaman tanaman padi hibrida

\begin{tabular}{lccc}
\hline \multirow{2}{*}{ Perlakuan } & \multicolumn{3}{c}{ Variabel } \\
\cline { 2 - 4 } & $\begin{array}{c}\text { Serapan } \mathrm{N} \\
\left(\mathrm{g}^{-12 n a m a n}{ }^{-1}\right)\end{array}$ & $\begin{array}{c}\text { BKT } \\
(\mathrm{g})\end{array}$ & $\begin{array}{c}\text { EPN } \\
(\%)\end{array}$ \\
\hline Varietas & & & \\
\hline Mapan P-05 & $89,05 \mathrm{c}$ & $45,76 \mathrm{c}$ & $23,88 \mathrm{c}$ \\
Intani 602 & $138,57 \mathrm{a}$ & $69,75 \mathrm{a}$ & $36,13 \mathrm{a}$ \\
SL-8SHS Sterling & $104,82 \mathrm{~b}$ & $53,74 \mathrm{~b}$ & $27,97 \mathrm{~b}$ \\
\hline Dosis Pupuk N & & & \\
\hline O kg ha $^{-1}$ & $52,86 \mathrm{c}$ & $33,57 \mathrm{c}$ & $21,08 \mathrm{c}$ \\
$100 \mathrm{~kg} \mathrm{ha}^{-1}$ & $160,64 \mathrm{a}$ & $71,33 \mathrm{a}$ & $31,67 \mathrm{~b}$ \\
$200 \mathrm{~kg} \mathrm{ha}^{-1}$ & $117,86 \mathrm{~b}$ & $64,35 \mathrm{~b}$ & $35,23 \mathrm{a}$ \\
\hline
\end{tabular}

Keterangan: Angka-angka yang diikuti huruf yang sama pada kolom yang sama pada setiap perlakuan tidak berbda nyata menurut DMRT $\alpha=0.05$. SNT = serapan $\mathrm{N}$ pada tanaman, $\mathrm{BKT}=$ bobot kering tanaman, $\mathrm{EPN}=$ efisiensi penggunaan $\mathrm{N}$ pada tanaman

Pasokan $\mathrm{N}$ yang optimal dapat menunjang pertumbuhan dan produksi tanaman dengan optimal pula. Pasokan hara $\mathrm{N}$ yang cukup ditandai dengan laju fotosintesis yang tinggi, pertumbuhan vegetatif yang baik, dan warna tanaman hijau tua (Munawar, 2011; Huang et al., 2021). Pasokan hara $N$ yang berlebihan dapat menunda pematangan tanaman. Selain itu, jika didukung dengan kondisi lingkungan yang cocok untuk pertumbuhan, dapat mengakibatkan tanaman banyak 
mengandung air (sukulen). Defisiensi $\mathrm{N}$ menyebabkan batang tanaman menjadi pendek dan kurus, daun kecil, pucat, kuninghijau, kemudian kuning, jingga, merah tunas lateral mati atau berhenti tumbuh (Huang et al., 2021; Rajiman, 2020). Oleh karena itu pemberian $\mathrm{N}$ dengan dosis berlebih dapat menurunkan tingkat pertumbuhan hingga hasil .

Tabel 1. menunjukkan tidak adanya interaksi pada variabel serapan $\mathrm{N}$ tanaman, bobot kering tanaman serta efisiensi penggunaan $\mathrm{N}$. Variabel serapan $\mathrm{N}$ tanaman, bobot kering tanaman serta efisiensi penggunaan $\mathrm{N}$ tanaman padi hibrida menunjukkan adanya variasi antar varietas.
Varietas Intani 602 memiliki tingkat serapan $\mathrm{N}$, bobot kering tanaman serta efisiensi penggunaan $\mathrm{N}$ tertinggi dibandingkan dua varietas lainnya.

Peningkatan efisiensi penggunaan $\mathrm{N}$ pada padi hibrida menunjukkan bahwa pemberian $\mathrm{N}$ dengan tepat dosis dapat meningkatkan efisiensi penggunaannya, sehingga mampu mendukung proses pertumbuhan, fisiologis, serta produksi oleh tanaman. Penyerapan nitrogen oleh tanaman meningkat dengan penambahan pupuk nitrogen, seperti yang dikemukakan Saputra (2016) bahwa peningkatan penyerapan nitrogen berkaitan dengan peningkatan ketersediaan $\mathrm{N}$ dalam tanah.

Tabel 2. Pengaruh dosis $\mathbf{N}$ terhadap Aktivitas Nitrat Reduktase, LAB, LPT, dan kerapatan stomata tanaman padi hibrida

\begin{tabular}{|c|c|c|c|c|}
\hline \multirow[b]{2}{*}{ Perlakuan } & \multicolumn{3}{|c|}{ Variabel } & \multirow[b]{2}{*}{$\begin{array}{c}\mathrm{KS} \\
\text { (unit } \mathrm{mm}^{-2} \text { ) }\end{array}$} \\
\hline & $\begin{array}{c}\text { ANR } \\
\left(\mu \mathrm{NO}_{2}^{-1} \mathrm{jam}^{-1}\right)\end{array}$ & $\begin{array}{c}\mathrm{LAB} \\
\left(\mathrm{g} \mathrm{dm}^{-2} \mathrm{minggu}^{-1}\right)\end{array}$ & $\begin{array}{c}\text { LPT } \\
\left(\mathrm{g} \mathrm{dm}^{-2} \text { minggu }^{-1}\right) \\
\end{array}$ & \\
\hline \multicolumn{5}{|l|}{ Varietas } \\
\hline Mapan P-05 & $1,24 \mathrm{a}$ & $0,005 a$ & $0,002 b$ & $0,55 \mathrm{c}$ \\
\hline Intani 602 & $1,52 \mathrm{a}$ & 0,008 a & $0,005 b$ & $0,64 b$ \\
\hline SL-8SHS Sterling & $1,35 a$ & $0,011 \mathrm{a}$ & $0,010 \mathrm{a}$ & $0,68 a$ \\
\hline \multicolumn{5}{|l|}{ Dosis Pupuk N } \\
\hline $0 \mathrm{~kg} \mathrm{ha}^{-1}$ & $1,55 \mathrm{a}$ & $0,008 \mathrm{a}$ & $0,005 a$ & $0,59 b$ \\
\hline $100 \mathrm{~kg} \mathrm{ha}^{-1}$ & $1,37 \mathrm{a}$ & $0,009 a$ & $0,006 a$ & $0,62 a b$ \\
\hline $200 \mathrm{~kg} \mathrm{ha}^{-1}$ & 1,19 a & $0,010 \mathrm{a}$ & $0,006 a$ & $0,66 \mathrm{a}$ \\
\hline
\end{tabular}

Keterangan: Angka-angka yang diikuti huruf yang sama pada kolom yang sama pada setiap perlakuan tidak berbda nyata menurut DMRT $\alpha=0.05$. ANR = aktivitas nitrat reduktase, $L A B=$ laju amisilasi bersih, LPT = laju pertumbuhan tanaman dan KS = kerapatan stomata.

Tanaman padi menyerap sekitar 33\% dari total $\mathrm{N}$ yang diberikan, dan sisanya hilang melalui proses kimia dan biologi (Hameed et al., 2019). Lin et al. (2009) mengemukakan bahwa pemberian dosis $\mathrm{N}$ pada tanaman padi, khususnya padi hibrida memerlukan dosis yang tepat dan sesuai agar didapatkan hasil yang optimal, karena peningkatan dosis pemberian $\mathrm{N}$ pada padi hibrida dengan sistem tanam yang sama belum tentu dapat diiringi dengan peningkatan hasil. Padi hibrida memiliki keunggulan mampu berproduksi lebih tinggi dibandingkan badi inbrida dikarenakan pada padi hibrida memiliki kemampuan pengoptimalan dalam pertumbuhan dan perkembangan pada organ-organ tanamannya dengan asupan $\mathrm{N}$ yang sama dengan padi inbrida, sehingga mampu menghasilkan jumlah gabah dengan kuantitas lebih tinggi (Amanullah \& Hidayatullah, 2016). Hal tersebut juga didukung karena tingginya aktivitas enzim dalam biji dalam mengkonversi sukrosa menjadi pati, serta proses fotosintesis yang 
lebih tinggi selama masa pematangan (Chu et al., 2019).

Variabel kerapatan stomata tanaman padi hibrida menunjukkan adanya variasi kerapatan stomata antar varietas. Varietas SL-8SHS Sterling memiliki tingkat kerapatan stomata tertinggi dibandingkan dua varietas lainnya (Tabel 2). Padi hibrida memiliki perkembangan daun yang sempit dan kutikula yang tebal yang meliputi jumlah stomata pada epidermis dan kemampuan menutup stomata dengan cepat.Padi hibrida memiliki karakter yang cukup toleran terhadap cekaman kekeringan, dimana hal tersebut dapat mempengaruhi pada tingkat kerapatan stomata masing-masing varietas
(Xiao et al., 2018). Seperti yang dikemukakan oleh Gupt et al. (2021) bahwa kerapatan stomata bervariasi antar individu tanaman dan dipengaruhi oleh genetik serta factor lingkungan seperti konsentrasi $\mathrm{CO}_{2}$, intensitas cahaya dan tekanan air.

Perbedaan pemberian dosis $\mathrm{N}$ menunjukkan pengaruh terhadap kerapatan stomata (Tabel 2). Hal tersebut diduga karena semakin meningkatnya pemberian dosis $\mathrm{N}$ akan meningkatkan kerapatan stomata baik dalam keadaan cukup air atau stress air, karena seperti diketahui bahwa tanaman juga memiliki kemampuan dalam mengatur pembukaan, penutupan dan kerapatan stomata sebagai salah satu tindakan adaptasi terhadap stres lingkungan (Singh et al., 2021).

Tabel 3. Pengaruh dosis $\mathrm{N}$ terhadap kadar klorofil a dan $\mathrm{b}$ tanaman padi hibrida

\begin{tabular}{lcc}
\hline \multirow{2}{*}{ Perlakuan } & \multicolumn{2}{c}{ Klorofil $\left(\mathrm{mg} \mathrm{g}^{-1}\right)$} \\
\cline { 2 - 3 } & $\mathrm{a}$ & $\mathrm{b}$ \\
\hline Varietas & $0,014 \mathrm{a}$ & $0,006 \mathrm{~b}$ \\
\hline Mapan P-05 & $0,016 \mathrm{a}$ & $0,007 \mathrm{~b}$ \\
Intani 602 & $0,017 \mathrm{a}$ & $0,010 \mathrm{a}$ \\
SL-8SHS Sterling & & $0,006 \mathrm{~b}$ \\
\hline Dosis Pupuk N & $0,015 \mathrm{a}$ & $0,007 \mathrm{ab}$ \\
\hline kg ha $^{-1}$ & $0,016 \mathrm{a}$ & $0,009 \mathrm{a}$ \\
$200 \mathrm{~kg} \mathrm{ha}^{-1}$ & $0,017 \mathrm{a}$ & $\mathrm{hg}$ \\
\hline
\end{tabular}

Keterangan: Angka-angka yang diikuti huruf yang sama pada kolom yang sama pada setiap perlakuan tidak berbda nyata menurut DMRT $\alpha=0.05$.

Varietas padi hibrida dengan kadar klorofil b tertinggi ditunjukkan oleh varietas SL-8SHS Sterling berbeda nyata dengan varietas Mapan P-05 dan Intani 602 (Tabel 3). Klorofil adalah komponen biokimia yang merupakan bahan utama dalam proses fotosisntesis serta komponen indikator kesehatan suatu tanaman, serta interaksinya dengan air, suhu, ketersediaan hara, $\mathrm{CO}_{2}$ dan sinar matahari dapat mempengaruhi tingkat fotosintesis (Munoz-Ortuno et al., 2017; Liu et al., 2018). Sytar et al. (2017) berpendapat bahwa tingkat ketersediaan asimilat pada padi varietas hibrida dapat mempengaruhi kadar klorofil pada daun padi varietas hibrida tersebut. Adapun perbedaan pemberian dosis $\mathrm{N}$ menunjukkan kadar klorofil $b$ tertinggi pada tanaman dengan pemberian dosis $\mathrm{N}$ sebanyak $200 \mathrm{~kg} \mathrm{ha}^{-1}$. Han et al. (2021) mengemukakan bahwa nitrogen merupakan salah satu penyusun klorofil, sehingga peningkatan pasokan nitrogen akan berdampak pada konsentrasi klorofil.

Hasil penelitian menunjukkan bahwa adanya perbedaan antar varietas dilihat dari kerapatan akar. Varietas Mapan P-05 
menunjukkan nilai tertinggi pada panjang akar, sedangkan SL-8SHS Sterling menunjukkan nilai tertinggi pada indeks luas daun, jumlah anakan dan tinggi tanaman. Adapun pada kombinasi dosis $\mathrm{N}$ yang diberikan, dosis $\mathrm{N} 100 \mathrm{~kg} \mathrm{ha}^{-1}$ secara garis besar mampu menunjukkan karakter pertumbuhan terbaik dibandingkan dosis 0 dan $200 \mathrm{~kg} \mathrm{ha}^{-1}$ khususnya pada variabel kerapatan panjang akar, jumlah anakan dan tinggi tanaman (Tabel 4). Ketersediaan nutrisi yang mencukupi akan menunjang proses fotosintesis yang tinggi, sehingga pertumbuhan maksimal. Sesuai dengan pendapat Munawar (2011) dan Xiao-Ming et al. (2014) yang menyatakan bahwa nitrogen berfungsi sebagai komponen asam amino, protein, klorofil, asam nukleat dan koenzim. Dosis $\mathrm{N}$ yang lebih tinggi menghasilkan tanaman dengan pertumbuhan yang lebih tinggi (Qiao et al., 2013). Namun di sisi lain, tanaman padi yang ukurannya terlalu tinggi juga mempunyai kelemahan, yaitu rentan terhadap kerebahan apabila di tanam di lapang.

Tabel 4. Pengaruh dosis $\mathrm{N}$ terhadap Indeks luas daun, kerapatan akar, jumlah anakan, dan tinggi tanaman padi hibrida.

\begin{tabular}{lcccc}
\hline Perlakuan & \multicolumn{4}{c}{ Variabel } \\
\cline { 2 - 5 } & ILD & $\begin{array}{c}\text { KPA } \\
\left(\mathrm{cm} \mathrm{cm}^{-3}\right)\end{array}$ & $\begin{array}{c}\text { JA } \\
\text { (batang) }\end{array}$ & $\begin{array}{c}\text { TT } \\
\text { (cm) }\end{array}$ \\
\hline Varietas & $3,39 \mathrm{~b}$ & $0,083 \mathrm{a}$ & $15,75 \mathrm{c}$ & $85,53 \mathrm{c}$ \\
\hline Mapan P-05 & $4,40 \mathrm{a}$ & $0,063 \mathrm{~b}$ & $19,75 \mathrm{~b}$ & $100,11 \mathrm{~b}$ \\
Intani 602 & $3,99 \mathrm{ab}$ & $0,067 \mathrm{~b}$ & $24,55 \mathrm{a}$ & $106,42 \mathrm{a}$ \\
SL-8SHS Sterling & & & & \\
\hline Dosis Pupuk N & $3,15 \mathrm{~b}$ & $0,062 \mathrm{~b}$ & $21,17 \mathrm{a}$ & $91,51 \mathrm{~b}$ \\
\hline 0 kg ha & & $0,074 \mathrm{a}$ & $20,51 \mathrm{a}$ & $103,33 \mathrm{a}$ \\
100 kg ha-1 & $3,66 \mathrm{~b}$ & $0,077 \mathrm{a}$ & $18,37 \mathrm{~b}$ & $97,22 \mathrm{ab}$ \\
\hline 200 kg ha & $4,99 \mathrm{a}$ & 0,1 &
\end{tabular}

Keterangan: Angka-angka yang diikuti huruf yang sama pada kolom yang sama pada setiap perlakuan tidak berbda nyata menurut DMRT $\alpha=0.05$. ILD = indeks luas daun, KPA = kerapatan panjang akar, JA = jumlah anakan, TT = tinggi tanaman.

Berdasarkan analisis ragam diperoleh hasil bahwa dosis nitrogen berpengaruh terhadap panjang malai, dan antar varietas terdapat perbedaan panjang malai. Tidak terdapat interaksi antara dosis nitrogen dan varietas pada variabel panjang malai. Peningkatan dosis $\mathrm{N}$ dari $0 \mathrm{~kg} \mathrm{ha}^{-1} \mathrm{ke} 100 \mathrm{~kg}$ $\mathrm{ha}^{-1}$ menunjukkan peningkatan hasil yang nyata, tetapi penambahan dosis $\mathrm{N}$ menjadi $200 \mathrm{~kg} \mathrm{ha}^{-1}$ tidak meningkatkan panjang malai. Antar varietas terdapat perbedaan karakter dilihat dari variabel jumlah anakan produktif, panjang malai, persentase gabah isi, serta produksi gabah per hektar (Tabel 5). Varietas Intani 602 memiliki jumlah anakan produktif, panjang malai, persentase gabah isi serta produksi gabah per hektar yang sama baiknya dengan SL-8SHS Sterling, jika dibandingkan dengan Mapan P-05 yang tergolong lebih rendah dari dua varietas padi hibrida lainnya.

Respon yang berbeda antar varietas terhadap dosis $\mathrm{N}$ menunjukkan bahwa varietas tersebut memiliki kemampuan yang berbeda-beda dalam pemanfaatan $\mathrm{N}$ yang diberikan. Setiap varietas memiliki kemampuan tersendiri untuk berproduksi berdasarkan asupan nutrisi yang diterimanya. Tingginya produksi varietas disebabkan oleh faktor genetik dari varietas 
dengan potensi hasil tinggi. Penambahan dosis $\mathrm{N}$ dapat meningkatkan panjang malai yang dihasilkan. Islam et al. (2012) menyatakan bahwa ketersediaan hara yang dibutuhkan tanaman dapat dipenuhi dengan menambahkan pupuk nitrogen yang sesuai untuk mempercepat penyerapan hara. Hal ini tentunya dapat menyebabkan tanaman lebih optimal dalam berproduksi. Namun demikian, penambahan $\mathrm{N}$ dengan dosis yang terus meningkat juga belum tentu dapat menghasilkan produksi yang maksimal. unsur hara $\mathrm{N}$ merupakan penunjang utama proses pertumbuhan, perkembangan dan penentu kualitas hasil tanaman (Hameed et al., 2019). Mardiyah (2021) mengemukakan bahwa tanaman membutuhkan nitrogen dalam jumlah besar untuk tumbuh. Nitrogen juga merupakan makroelemen utama yang menyusun protein dan merupakan komponen utama protoplasma, kloroplas, dan enzim. Peran nitrogen terkait dengan aktivitas fotosintesis dan oleh karena itu diperlukan untuk metabolisme dan respirasi. Pembentukan anakan tanaman padi, tinggi tanaman, luas daun, dan hasil gabah dipengaruhi oleh ketersediaan N (Saputra, 2016).

Tabel 5. Hasil dan komponen hasil pada hibrida pada berbagai taraf pemupukan $\mathrm{N}$

\begin{tabular}{lccccc}
\hline \multicolumn{5}{c}{ Perlakuan } & \multicolumn{5}{c}{ Variabel } \\
\cline { 2 - 6 } & $\begin{array}{c}\text { JAP } \\
\text { (batang) }\end{array}$ & $\begin{array}{c}\text { PM } \\
(\mathrm{cm})\end{array}$ & $\begin{array}{c}\text { PGI } \\
(\%)\end{array}$ & $\begin{array}{c}\text { PGPH } \\
\left(\mathrm{t} \mathrm{ha}{ }^{-1}\right)\end{array}$ & $\begin{array}{c}\text { BSB } \\
(\mathrm{g})\end{array}$ \\
\hline Varietas & & & & & \\
\hline Mapan P-05 & $8,15 \mathrm{~b}$ & $19,05 \mathrm{~b}$ & $46,35 \mathrm{~b}$ & $7,42 \mathrm{a}$ & $20,42 \mathrm{a}$ \\
Intani 602 & $15,46 \mathrm{a}$ & $21,90 \mathrm{a}$ & $55,78 \mathrm{a}$ & $7,03 \mathrm{ab}$ & $21,78 \mathrm{a}$ \\
SL-8SHS Sterling & $16,71 \mathrm{a}$ & $21,75 \mathrm{a}$ & $45,41 \mathrm{~b}$ & $5,94 \mathrm{~b}$ & $21,70 \mathrm{a}$ \\
\hline Dosis Pupuk N & $13,49 \mathrm{a}$ & $21,60 \mathrm{a}$ & $50,72 \mathrm{a}$ & $5,94 \mathrm{~b}$ & $21,30 \mathrm{a}$ \\
\hline 0 kg ha $^{-1}$ & $13,24 \mathrm{a}$ & $20,40 \mathrm{~b}$ & $48,43 \mathrm{a}$ & $7,47 \mathrm{a}$ & $21,90 \mathrm{a}$ \\
$100 \mathrm{~kg} \mathrm{ha}^{-1}$ & $13,60 \mathrm{a}$ & $20,70 \mathrm{~b}$ & $48,40 \mathrm{a}$ & $6,97 \mathrm{ab}$ & $20,68 \mathrm{a}$ \\
\hline
\end{tabular}

Keterangan: Angka-angka yang diikuti huruf yang sama pada kolom yang sama pada setiap perlakuan tidak berbda nyata menurut DMRT $\alpha=0.05$. JAP = jumlah anakan produktif, $P M=$ panjang malai, $\mathrm{PGI}=$ persentase gabah isi, $\mathrm{PGPH}=$ produksi gabah per-hektar dan $\mathrm{BSB}=$ bobot 1000 butir

\section{SIMPULAN}

1. Respon varietas padi hibrida sangat beragam terhadap pemupukan $\mathrm{N}$.

2. Serapan $N$, efisiensi penggunaan $N$ tertinggi dicapai pada varietas Intani 602 masing-masing sebesar $138,57 \mathrm{~g}$ per tanaman, dan 36,13\%. Serapan N tanaman padi tertinggi dicapai pada dosis $\mathrm{N} 100 \mathrm{~kg} \mathrm{ha}^{-1}$, dan efisiensi penggunaan $\mathrm{N}$ tertinggi pada dosis $\mathrm{N} 200 \mathrm{~kg} \mathrm{ha}^{-1}$.

3. Varietas Mapan P05 merupakan varietas yang mampu menghasilkan gabah kering giling sebesar 7,42 $\mathrm{t} \mathrm{ha}{ }^{-1}$, pemupukan dengan dosisi mampu menghasilkan gabah kering giling sebesar $7,47 \mathrm{tha}^{-1}$.

\section{UCAPAN TERIMAKASIH}

Penulis mengucapkan terimakasih yang sebanyak-banyaknya kepada LPPM Universitas Jenderal Soedirman yang telah membiayai penelitian ini melalui skim Peningkatan Kompetensi Tahun Anggaran 2021. Penulis juga mengucapkan terima kasih kepada Rizki Fabiofansyah yang telah 
membantu jalannya penelitian dari persiapan dan pengambilan data di lapangan

\section{DAFTAR PUSTAKA}

Amanullah \& Hidayatullah. (2016). Influence of organic and inorganic nitrogen on grain yield and yield components of hybrid rice in Northwestern Pakistan. Rice Science. 23(6):326-333.

Amirrullah, J., Prabowo, A., \& Yustisi. (2018). Potensi hasil varietas inbrida padi sawah irigasI (INPARI) dan limbahnya sebagai pakan ternak di Kabupaten Musi Rawas Provinsi Sumatera Selatan. Jurnal Triton, 9(2), 185-190.

BPS. (2021). STATISTIK Luas Panen dan Produksi Padi (Angka Tetap ). 22, 1-20.

Chu, G., Chen, S., Xu, C., Wang, D., \& Zhang, $X$. (2019). Agronomic and physiological performance of indica/japonica hybrid rice cultivar under low nitrogen conditions. Field Crops Research. 243: 1-10.

Djaman, K., Mel, V.C., Ametonou, F.Y., ElNamaky, R., Diallo, M.D., \& Koudahe, K. (2018). Effect of nitrogen fertilizer dose and application timing on yield and nitrogen use efficiency of irrigated hybrid rice under semi-arid conditions. Journal of Agricultural Science and Food Research 9(2):223.

Dong, X., Ying, Z., Zhi-feng,C., Chao, H., Lei, H., Shi, Q., Pei, W., Guo-dong, L., Haiyan, W., \& Hong-cheng, Z. (2020). Yield characteristics of japonica/indica hybrids rice in the middle and lower reaches of the Yangtze River in China. Journal of Integrative Agriculture, 19(10),2394-2406. https://doi.org/10.1016/S20953119(19)62872-8

Good, A. G., Shrawat, A. K., \& Muench, D. G. (2004). Can less yield more? Is reducing nutrient input into the environment compatible with maintaining crop production ?9(12).

https://doi.org/10.1016/j.tplants.2004 .10 .008

Gupt, S.K., Chand, R., Mishra, V.K., Ahirwar, R.N., Bhatta, M., \& Joshi, A.K. (2021). Spot blotch disease of wheat as influenced by foliar trichome and stomata density. Journal of Agriculture and Food research. 6:100227.

Hameed, F., Xu, J., Rahim, S.F., Wei, Q., Khalil, A.R., \& Liao, Q. (2019). Optimizing nitrogen options for improving nitrogen use efficiency of rice under different water regimes. Agronomy. 39(9):1-18.

Han, T., Wang, B., Wu, Z., Dai, C., Zhao, J., Mi, Z., Lv, Y., Zhang, C., Miao, X., Zhou, J., Li, X., Sun, Z., Yang, J., Zhai, W., Zheng, F., Chen, Z., \& Zhang, B. (2021). Providing a view for toxicity mechanism of tetracycline by analysis of the connections between metabolites and biologic endpoints of wheat. Ecotoxicology and Environmental Safety. 212:111998.

Hasanalideh, A.H. \& Hojati, M. (2012). Enhancing yield and nitrogen use efficiency of Brassica Napus L. using an integrated fertilizer management. Advances in Environmental Biology. 6(2):641-647.

Huang, Z., Lv, Q., Hossain, M.A., Wu, Z., Tan, F., Peng, Y., Xin, Y., Zhu, L., \& Yuan, L. (2021). Low fertilizer inputs do not adversely affect yield or performance of Indica hybrid rice. Scientia Agriola. 79(4):1-17.

Imran, A., \& Suriany. (2009). Penampilan dan produktivitas padi Hibrida SI-8-SHS di Kabupaten Pinrang Sulawesi Selatan. Buletin Plasma Nutfah 15(2): 54-58.

Islam, M.Z., Sattar, M.A., Ashrafuzzaman, A., Saud, H.M., \& Uddin, M.K. (2012). Improvement of yield potential of rice through combined application of biofertilizer and chemical nitrogen. 
African Journal of Micrbiology Research. 6(4):745-750.

Lin, X., Zhu, D., Chen, H., \& Zhang, Y. (2009). Effects of plant density and nitrogen application rate on grain yield and nitrogen uptake of super hybrid rice. Rice Science. 16(2):138-142.

Liu, H., Li, M., Zhang, J., Sun, H., Long, Y., Wu, L., \& Zhang, Q. (2018). PCA based model on chlorophyll content diagnosis of winter wheat. IFAC Papers Online. 51-17:643-647.

Lyu, T., Shen, J., Ma, J., Ma, P., Yang, Z., Dai, Z., Zheng, C., \& Li, M. (2021). Hybrid rice yield response to potted-seedling machine transplanting and slowrelease nitrogen fertilizer application combined with urea topdressing. The Crop Journal. 9:915-923.

Mardiyah, A. (2021). Optimasi pemupukan urea dalam peningkatan produksi padi gogo lokal aceh timur. Agrosamudra Jurnal Penelitian. 8(1): 41-48.

Munawar, A. (2011). Kesuburan Tanah dan Nutrisi Tanaman. IPB Press. Bogor.

Munoz-Ortuno, M., Serra-Mora, P., HerraezHemandez, R., Verdu-Andres, J., \& Campins-Falco, P. (2017). A new tool for direct non-invasive evaluation of chlorophyll a content from diffuse reflectance measurements. Science of the Total Environment. 609:370-376.

Muthohharoh, N., Sasongko, L.A., \& Awami, S.N. (2018). Preferensi petani terhadap beberapa varietas padi di Kecamatan Blora Kabupaten Blora. AGRONOMIKA, 12(2).

Palanivell, P., Ahmed, O.H., Majid, N.M.A., Jalloh, M.B., \& Susilawati, K. (2015). Improving Lowland Rice (O. sativa L. cv. MR219) Plant Growth Variables, Nutrients Uptake, and Nutrients Recovery Using Crude Humic Substances. The Scientific Worls Journal. 2015:906094.

Peng, J., Xiao-bing, X., Min, H., Xue-feng, Z.,
Rui-chun, Z., Jia-na, C., Dan-dan, W., Bing, X., Fu-xian, X., Hong, X., \& Yingbin, Z. (2015). Comparisons of yield performance and nitrogen response between hybrid and inbred rice under different ecological conditions in southern China. Journal of Integrative Agriculture. 14(7):1283-1294.

Pradipta, A.P., Yunus, A., \& Samanhudi. (2017). Hasil padi hibrida Genotipe T1683 pada berbagai dosis pupuk NPK. Agrotech Res J. 1(2): 24-28.

Proklamasiningsih, E. Priyambada, I.D., Rachmawati, D. (2013). Laju Fotosintesis dan Kandungan Klorofil Kedelai pada Media Tanam Masam dengan Pemberian Garam Aluminium. Agrotrop: Journal on Agriculture Science, 2(1), 17-24.

Purbajanti, E.D., Soetrisno, R.D., Hanudin, E., \& Budhi, S.P.S. (2010). Penampilan fisiologi dan hasil rumput benggala (Panicum maximum Jacq.) pada tanah salin akibat pemberian pupuk kandang, gypsum dan sumber nitrogen. JIPI. 12 (1): 61-67

Qiao, J., Yang, L., Yan, T., Xue, F., \& Zhao, D. (2013). Rice dry matter and nitrogen accumulation, soil mineral $\mathrm{N}$ around root and $\mathrm{N}$ leaching, with increasing application rates of fertilizer. Europ. J. Agronomy. 49:93-103.

Rajiman. (2020). Pengantar pemupukan. Deepublish. Yogyakarta. 128 hal.

Rajput, A., Rajput, S.S., \& Jha, G. (2017). Physiological parameters leaf area index, crop growth rate, relative growth rate and net assimilation rate of different varieties of rice grown under different planting geometries and depths in SRI. Int. J. Pure App. Biosci. 5 (1): 362-367.

Ramija, K.E. (2013). Model Optimum Budidaya Padi Intensif Dengan Pertimbangan Gas Metan Pada Sawah Irigasi Teknis. Disertasi. Sekolah 
Pascasarjana Universitas Sumatera Utara, Medan.

Saputra, I. (2016). Efek dosis pupuk nitrogen dan varietas terhadap efisiensi pemupukan, serapan hara $\mathrm{N}$ dan pertumbuhan padi lokal Aceh dataran rendah. Agrosamudra. 3(2):61-71.

Septiadi, D., \& Joka, U. (2019). Analisis respon dan faktor-faktor yang mempengaruhi permintaan beras Indonesia Agrimor 4 (3) 42-44.

Setyorini, D., Widowati, L.R., \& Kasno, A. (2020). Respon varietas padi berpotensi hasil tinggi terhadap pemupukan nitrogen pada Inceptisols bertekstur ringan dan berat. Jurnal Tanah dan Iklim 44(1), 37-49.

Singh, A.P., Mani, B., \& Giri, J. (2021). OsJAZ9 is involved in water-deficit stress tolerance by regulating leaf width and stomatal density in rice. Plant Physiology and Biochemistry. 162:161170.

Sridevi, V., \& Chellamuthu, V. (2015). Growth analysis and yield of rice as affected by different system of rice intensification ( SRI ) practices I $\times \mathrm{w} \times \mathrm{k} \times$ number of leaves plant land area occupied by the plant RGR. International Journal of Research in Applied, Natural and Social
Sciences 3(4), 29-36.

Satoto \& Suprihatno, B. (2008). Pengembangan padi hibrida di Indonesia. Iptek Tanaman Pangan, 3(1), 27-40.

Sytar, O., Brestic, M., Zivcak, M., Olsovska, K., Kovar, M., Shao, H., \& He, X. (2017). Applying hyperspectral imaging to explore natural plant diversity towards improving salt stress tolerance. Science of the Total Environment. 578::90-99.

Xiao, M., Li, Y., Lu, B., \& Miao, Z. (2018). Response of Physiological Indicators to Environmental Factors under Water Level Regulation of Paddy Fields in Southern China. Water. 10:1772.

Xiao-Ming, Y., Wei, L., Song-Wei, W., QiRong, S., \& Xiao-Hua, L. (2014). Effect of Nitrogen Starvation on the Responses of Two Rice Cultivars to Nitrate Uptake and Utilization. Pedosphere. 24(5):690698.

Xie, X., Shan, S., Wang, Y., Cao, F., Chen, J., Huang, M., \& Zou, Y. (2019). Dense planting with reducing nitrogen rate increased grain yield and nitrogen use efficiency in two hybrid rice varieties across two light conditions. Field Crops Research. 236:24-32. 